\title{
RESEÑA: TARZAN Y EL FILOSOFO DESNUDO
}

\author{
RODRIGO PARRA SANDOVAL \\ ARANGO EDITORES. 1a. Edic. Mayo 96 - 526 páginas \\ CARLOS BOLIVAR BONILLA \\ Director Postgrado en Educación Física \\ Universidad Surcolombiana, Neiva
}

Tarzán y el filósofo desnudo es una exquisita mamadera de gallo a costillas del acartonado y prepotente academicismo que vegeta en la Universidad colombiana. Es también una inquietante reflexión sobre la precariedad de la condición humana que tanto se intenta ocultar, especialmente con las máscaras del amor, la amistad o el estudio.

Por esto, el humor corrosivo de la obra no impide poner a pensar con seriedad, sobre algunos temas trascendentales de la filosofía y de la vida cotidiana. Son excluyentes estas dos últimas actividades? Es posible el desarrollo de un pensamiento filosófico autónomo en el país o hay que seguir condenados a mal repetir los clásicos alemanes? Concebir un sistema de pensamiento implica una postura dictatorial y sectaria? El amor no existe más que como incesante búsqueda, como efímera arma contra la soledad? Requiere la docencia universitaria exitosa más de la creatividad erótica que de la pedagogía?

La obra está escrita de manera nada convencional, por semestres de un plan de estudios, en los cuales se entrecruzan el lector y el escritor hablando incluso de la misma novela, mediante relatos breves e intensos. Los relatos conservan cierta autonomía pero, al mismo tiempo, van entretejiendo las situaciones y los personajes que configuran la unidad narrativa.

Resulta sumamente entretenido leer cómo el detective consultor, Faraón Angola, especializado en asuntos de amor y ex-profesor universitario de filosofía, debe evitar un crimen que ha soñado un colega, el filósofo caleño. Faraón y la bella Deifilia, su compañera de pesquisa, construirán múltiples hipótesis de sentido sobre el crimen mientras experimentan una amplia gama de copulas y orgasmos, debidamente aliñados con vino y queso. 
Buscando al asesino será sorprendente encontrar en Cali aHegel bailando salsa, Heidegger bebiendo zumo de naranja, Nietzche comiendo chontaduro y a Marx conferenciando sobre la mercancía, para la Cámara de Comercio. Y Tarzán? Tarzán puede ser usted mismo, un hombre que vivió feliz hasta que le dio por filosofar, preguntarse por su identidad, sú origen, ir a la Universidad, ofrecer seminarios en la selva, civilizar a los pigmeos, revolcar a Jane en cumplimiento de estricto horario, burocratizarse.

Se puede admirar y compadecer al filósofo caleño quien empeñado en escribir la historia de la filosofía colombiana, va perdiendo el amor de su Ofelia y ganándose, de sus malquierientes, pesados ladrigrafittis con frases como éstas: "Filósofo caleño: crees, creas, crías o croas" o "un filósofo caleño es como un torero alemán".

Un filósofo que decide renunciar a toda una vida de hipocresía y mascarada, desnudarse, para dedicarse a lo que verdaderamente ha deseado: escribir. $Y$ termina escribiendo en un sótano, con música de Wagner y vestido como Tarzán, su héroe predilecto de infancia. Así, el detective, el filósofo caleño, los filósofos clásicos y Tarzán se confunden en un solo personaje.

El crimen podría cometerlo cualquiera, hasta el anónimo lector.

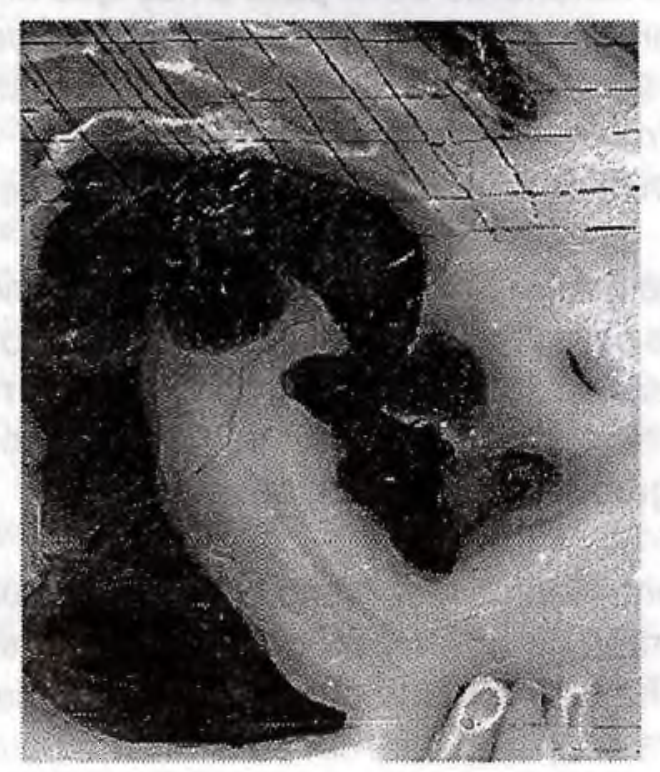

